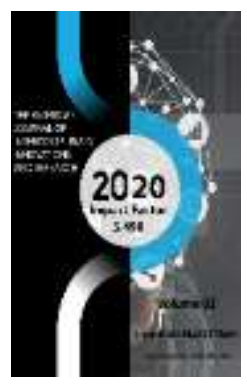

\title{
«The Muslim Brotherhood» Religious And Political Organization: Past And Present
}

\author{
Komiljon Shermukhamedov \\ Researcher, International Islamic Academy of Uzbekistan
}

Journal Website:

http://usajournalshub.c om/index,php/tajiir

Copyright: Original content from this work may be used under the terms of the creative commons attributes 4.0 licence.

\section{ABSTRACT}

The experts supposed the increase of the religious factor throughout the world in the beginning of the 21st century. According to the various sources the roots of the religious extremism and terrorism date back to the remote past. It is fact that the Kharijites, the religious and political sect which was appeared in 657, have declared themselves as true Muslims while claimed that those who had not agreed with them were apostates and struggled against them. But it is well worth emphasizing that they have never threatened the social stability and progress as much as today. Because, in our days, the religious extremism and terrorism has a global nature and it threatens all countries and regions of the world equally. Especially, it is not secret that "The Arab Spring" conflicts which have occurred in the Middle East countries were carried out in the guise of the religion by the powers and these powers have used the extremist and terrorist group to reach their goals.

The study of the activities of "The Muslim Brotherhood" which was appeared in the city of Ismailia of Egypt, 1928 allows us to understand the true essence of the religious extremism.

The suppositions given in the abstract allow us to conclude that, on the one side, the extremist ideas in the guise of Islam which have developed for a long time were entirely used in the views of Hasan alBanna, Sayyid Qutb and their followers, on the other, "The Muslim Brotherhood" has developed and systematized the organizing systems and methods of all sects and organizations before them in their own practice. It is fact that the scientific and critical study of the activity methods and ideological bases of this organization is important in the research of the true essence of the modern extremism.

\section{KEYWORDS}

Fanaticism, religious extremism, terrorism, infidel, sin, heresy, idolatry, assassinate, revolutionary struggle, «The Muslim Brotherhood», «Arab Spring», rebellion 


\section{INTRODUCTION}

According to the sources, roots of the religious extremism and terrorism date back to the remote past. But it is worth emphasizing here that the religious extremism and terrorism have never threatened the stability and progress of social life as much as today. Because, at present, the religious extremism and terrorism has a global nature and they are threatening all countries and regions of the world equally. In this case, it is worth mentioning that the struggle against the religious extremism and terrorism has already become a very actual problem concerning the future of mankind. Societies have actual complex tasks on this subject that it is necessary to be solved as soon as possible.

In fact, if we notice the history of these extremist movements disguised under the name of Islam, we can find that theirs basic roots date back to the activities of the religious and political sect named the Kharijites (from Arabic - the separators and rebels) who was appeared in the period of Ali (may Allah bless him). The Kharijites, finding themselves true Muslims, have called those who had not agreed with them apostates and declared a ruthless war against them.

\section{RESULTS AND DISCUSSION}

The Kharijites have been extreme supporters of the rules of "pure» Islam as they had interpreted [4, p.235]. They were the first sect who has called those who had not accepted their views and taken part in their activities infidels and has developed the idea of «jihad» against them and has started to murder the rulers within the method of terror. Furthermore, according to the Kharijites, loyalty of a pious man to the pillars of Islam must be estimated in accordance with his actions. The Kharijites have developed the idea that it would be necessary not to submit to the rulers who had not followed the rules of «pure» Islam as they have interpreted and to declare a war against such kind of rulers. These ideas have caused the struggle methods for the power based on terror and violence to be developed as well as thousands of people to be murdered.

Besides, the ruthless and cruel sect in the history of Islam named the Azraqites was found by Nafi' bin al-Azraq (died 685) and had an important and special role in the development of the fanaticism idea and practice.

They have called all Muslims who had committed big sins «infidels» and given a legal permission to declare jihad against those who had not followed their teaching and to murder even women, children and old people.

The extremist movement of the Karmates was appeared at the end of the gth century in Iraq and they have not accepted the pillars of Islam and declared the action of Hajj of heresy and idolatry. Furthermore, according to their teaching, «the divine worships such as a prayer, fast, zakat and others are not obligations, they are only additional orisons. These are considered as a gratitude for Razzaq (who gives all creatures subsistence). Allah needs no worships of mankind. People may have a choice to perform these obligations or not to perform them at all. They have own choice in performing of these obligations» $[1$, p.20]. The name of this movement has originated from the word of «Karmat» which was used as the founder's nickname - Hamdaan bin al-Ash'as and means a «short leg» or «red eye» in English. 
The Karmates have committed many crimes which were stigmas in the history of Islam. They have attacked caravans during the period of Hajj and committed a robbery. Especially in 930, they invaded Mecca, committed a robbery there, murdered the citizens of Mecca and took them prisoners. They «Hajar al-asvad» (the black stone in Mecca) into two parts and took it away to Bahrain. Only 20 years later they returned it to Mecca in exchange of a huge payment [5, p.27].

The Assassins, the terrorist group named «The Hashishites» (from Arabic - those who accepts narcotics) who was developed at the end of the 11th century in Iran has developed the practice of attempting on the life of rulers who had not agreed with them in the way of seizing of the power. They have threatened a lot of ruler for a long time, as result of it the rulers of some European countries had to pay them for ensuring their own security. The English word «assassinate» means to attempt on one's life and was originated from the term «Hashishites». The name of this group shows that it has threatened the countries' security on a large scale. Furthermore, they have forced people and young men to accept narcotics and to believe in to enter the Paradise after their death. This method is widely used by the modern terrorist groups [3, p.310].

It is worth emphasizing that the activities of such kind of sects which were based on terror and violence and threatened the unity of faith were condemned by the scholars and theologians of that time and persecuted by the rulers. For example, the Umayyad and Abbasid caliphs have carried out policy aimed to destroy the Hashishites.

But it is worth saying that the ideas and forms of the practice mentioned above which were contradictory to the true essence of Islam at all have developed at a later date. The development of the extremist ideas appeared in the guise of the flag of Islam in a unique way by Ahmad bin Taymiya (1263-1328) may be an evidence of it. Ibn Taymiya who created the teaching of the "revolutionary struggle» in Islam has advanced some views that «if a ruler had not performed all obligations of Islam in the country under his authority, he would be an infidel. An infidel did not have a right to rule Ummah. That is why it was necessary to declare jihad against him and to change a ruler of the country which was not ruled by sharia radically» $[6$, p.36].

Ibn Taymiya's ideas based on fanaticism laid down a foundation of the terrorist acts which were occurred in Central Arabia in the guise of the idea return Islam «into its fundamental conditions» in the middle of 18th century and have black spots in the history murdering innocent people.

The ideas that aroused hostility among Muslim societies and justified the way of obtaining the political power with violence have caused the radical sects such as «The Muslim Brotherhood» to be developed in the 20th century. It is worthy to emphasize that the study of the activities of «The Muslim Brotherhood» which was found in Egypt, 1928 by Hasan al-Banna is very important to understand the essence of the modern extremism. Indeed, this organization has developed the structure of the organization, ideological and dogmatic views and methods of activities on which the modern religious extremism based in the history. The leaders of the organizations such as Hasan al-Banna and Sayyid Qutb have caused the religious fanaticism groups to be more radical with their propagandas. 
Although the Egyptian government allowed "The Muslim Brotherhood» to act openly in the beginning of the 1950th years, this permission was cancelled and lots of active members of the organization were sentenced to prison as a result of a desire of the leaders of the organization for influencing on the activity of the Revolutionary Council of Egypt. Some of members of the organization had to run away to Saudi Arabia, Syria, Jordan and Lebanon.

It is worthy emphasizing in this place that we know from the history that the movement of «The Muslim Brotherhood» has threatened the leaders of the country. Particularly, the organization attempted to murder the then President Jamal Abdul Nasir on October 26, 1954. After this attempt, 3000 members of the organization were sent to prison, 6 of them were executed. "The Muslim Brotherhood» organization has acted underground, attempted to organize a revolution and murder Jamal Abdul Nasir several times latterly.

Anwar Sadat came to power on October 15, 1970 after Jamal Abdul Nasir and became famous for his policy of «the open door» not only in Egypt, but in all Arabic World. Anwar Sadat who was hostile towards Jamal Abdul Nasir has not followed his way of ruling at all. During his reign the role of Islam was increased in the country. The new government of Egypt has appreciated the activities of various religious and political highly and tolerated them. Even Anwar Sadat established friendly relations with «The Muslim Brotherhood» and declared that he was proud of the founder of this organization, Hasan al-Banna in summer, 1971 [4, p.253]. He has started to discharge members of the organization who were sent to prison by the government of Jamal Abdul Nasir allowing the movement to act freely. There were future leaders Ma'mun al-Khudaybi, Muhammad Hamid Abu Hasr and others beside the then leader of the organization, Hasan alKhudaybi who was sentenced to prison in 1965 among the discharged prisoners.

The President of Egypt, Anwar Sadat had mainly a political conciliatory approach towards the fanaticism sects like «The Muslim Brotherhood» in order to use them against the «radical» powers in the country in his time. As a result of it an acute politicization of Islam, appearance of new extremist groups which had fanatic ideas, reinforcement of the current movements was happened. By the end of 1970, 22 extremist organizations acted in the country [7, p.43]. This increase in quality and compliment for the movement of «The Muslim Brotherhood» reached its logical finish with an attempt on Anwar Sadat's life by the organization of «Al-Jihad» which was formed under the influence of «The Muslim Brotherhood» on October 6, 1981 [2, p.147].

It is worthy emphasizing that the activity of «The Muslim Brotherhood» was enlivened and they requested the government to formalize their movement after Hosni Mubarak was voted as a President. In response to it, the government began to struggle against the opposition powers in the country in a large scale. Almost 300 extremists were sent to prison and 4 of them who were accused of murder of Anwar Sadat were executed.

The extremists have threatened the life of Hosni Mubarak several times. He was adjudged to die in 1982 by the underground extremist group «Al-Aqsaa». He was attempted on his life in New York, 1993, but this attempt was failure. The car of Hosni Mubarak was shot on July 26, 1995, in Addis-Ababa. One of the citizens assaulted Hosni Mubarak and tried to hit him with a knife during election campaigning in 
Port Said, 1999, but was shot by the bodyguards.

In the beginning of the 21st century the activity of «The Muslim Brotherhood» which has turned into the common religious movement for all Arabic countries began to deal with an open political activity. They have frequently demonstrated a protest and claimed the government to reform under a slogan of «Islam is a solution for problems" as well as Hosni Mubarak to send in his resignation.

It is worthy emphasizing that «The Muslim Brotherhood» movement did not play the leading part in the protest marches which began on January 25, 2011, in Cairo and finished on February 11 with Hosni Mubarak's resignation [8, p.280-281]. Because they knew well that their traditional slogan («lslam is a solution for problems») was not useful in such kind of extraordinary demonstrations. In spite of it, more than 30 members of «The Muslim Brotherhood» organization were discharged in various cities of the country as a result of the demonstrations. These progresses were for the benefit of the organization.

As a result of it, the leader of the party «Justice and liberty» which was a political arm of «The Muslim Brotherhood» organization, Mohamed Morsi was elected as a President of Egypt on June 30 according to the results of two-stage elections which were held for an election of the President of the country in 2012. Mohamed Morsi emphasized in his statement that he was a president not only for «The Muslim Brotherhood", but for all Egyptians in the country and wanted to leave the organization after he had won the election.

Mohamed Morsi has primarily attempted to expand the president's absolute powers, as well as to subjugate the judicial system during his activity. It should be noted that the crisis of economic regress during the period of Hosni Mubarak was considered as the main reason for the «Arab Spring». However, members of the new government who came to power also said that they would work on the basis of liberal reforms adopted on July of 2004. This is due to the fact that economic growth has accelerated in recent years because of the new reforms introduced in the country. In turn, it showed that the economic policies carried out by the ousted President Hosni Mubarak were in a right way.

It was stated on November 30, 2012 that Islamic laws were the main source of jurisprudence. Due to it, a new constitution with a fully Islamic content was adopted and a referendum was held in late December. The President Morsi approved it despite of disagreement of the majority. The administration under the influence of the «Muslim Brotherhood» soon failed.

Protests of Egyptian people against Mohamed Morsi's policy have continued unabated since December of 2012. The fact is the citizens of big cities and the military did not vote for Morsi. The military has always been the most united and literate class of people in Egypt. There is an opinion that the military could have retained Morsi saving the government in their hands just on the day he won the election. However, it would be considered as a military coup and the international community would react it negatively.

On June 30, 2013, one year after Mohamed Morsi was elected as a president, he wanted to celebrate this date. In fact, protests against him had reached its peak and an organization of youth people called «Tamarrud» (Rebellion) demanded Morsi's resignation and collected 
22,5 million signatures in four days [9]. Millions of people in Cairo, Alexandria and other cities demanded Morsi's resignation and launched attacks on the local offices of the "Muslim Brotherhood» on June 30.

The minister of the defense, Abdel Fattah elSisi, on behalf of the military leadership, demanded the President to restore peace in the country within two days on July 1, 2013. However, the President Morsi failed to comply this demand. The army seized power and ousted members of the «Muslim Brotherhood» from the government on July 3 [10].

How it can be appreciated Morsi's one-year activity? The previous events in Turkey and Algeria were only repeated in a different way. The «Muslim Brotherhood» has established its monopoly while Morsi has failed to solve acute social and economic problems. His opponents have accused him of failing to carry out his election promises and to rule the country.

The Egyptian government declared the «Muslim Brotherhood» organization as an official terrorist organization on December, 2013. Later the same decision was issued in Saudi Arabia on March 7, 2014 [11]. As a result, many supporters of the «Muslim Brotherhood» were arrested. Such actions are often considered as military coups. The process that began in Egypt on July 3, 2013 should be seen as a strengthening of the opposition of people against Morsi's authoritarianism by the army. In fact, the military has prevented a bloody civil war that would be occurred in Egypt.

The Minister of the Defense, Abdel Fattah elSisi was elected as the President of Egypt in the elections held on May, 2014. During the past period of instability, Egypt has suffered both economically and morally.
In general, it should be stated that it was clear that the «Muslim Brotherhood» organization's period at the helm of the government was short. This is evidenced by the events in Turkey, Algeria or the Taliban's attempts to establish a theocratic state in Afghanistan.

The main focus of the new government was aimed at the fight against local reactionary and international terrorist groups in Egypt. As a result of the "Arab Spring", the ongoing conflicts in Iraq, Syria and Yemen have been a great lesson for the Egyptians. The Egyptian governments strong position towards fanatical groups has been supported by the majority of the population.

\section{CONCLUSION}

The analysis given above enables to conclude that the activity which has been carried out by «The Muslim Brotherhood» for a long time caused ideologically the periodical social and political instability to be developed in Egypt as well as radical religious and political organizations to be appeared in other Arabic countries.

In this case, the study of the history, activity methods and ideological foundations of organizations such as «The Muslim Brotherhood» from the point of scientific and critical view has a scientific, theoretical and practical importance in understanding of the real essence and face of the modern extremism. To carry out a ruthless struggle against these sects and give proofs that the fanatic powers which conduct terrorist acts are absolute strange for Islam is one of the actual tasks. 


\section{REFERENCES}

1. Abul Husayn Maliti. «Kitabut tanbeeh war raddu ala hawaa wal bidai».

2. Borisov A.B. «Rol islama vo vnutrenniy i vneshney politike egipta XX vek». Moscow, 1991.

3. Islom. Ensiklopedia: A-H. Tashkent.: «O'zbekiston milliy ensiklopediyasi» Davlat ilmiy nashriyoti. 2003.

4. Khasanov A. Islom tarihi. - Tashkent, «Toshkent islom universiteti» nashriyot-matbaa birlashmasi, 2008.

5. Khusniddinov Z. Islom Yunalishlar, mazhablar, oqimlar. - Tashkent, «Movarounnahr» nashriyoti, 2000.

6. Korovikov A.V. Islamskiy ekstremizm v arabskikh stranakh. - Moscow, «Nauka», 1990.

7. «Narodi Azii i Afriki», 4/1984.

8. Sistemniy monitoring globalnikh riskov: Arabskaya vesna 2011 goda / Otv. red. A.V. Korotayev, Y.V. Zinkina, A.S. Kholdunov. - Moscow: Izdatelstvo LKI, 2012.

9. Khronika perevorota $v$ Egipte $v 2013$ godu. http://ria.ru/arab eg/20130629/946572389.html

10. Revolyutsiya $v$ Egipte: voennaya perezagruzka. http:/ru.arab eg/20130704/947487407.html

11. http://ria.ru/tags/organitation Bratya musulmane/ 